\title{
AMS Congressional Fellow AJ Stewart: From Baking Bread to Using Mathematics for Social Justice
}

\section{Scott Hershberger}

Each year, the AMS sponsors a Congressional Fellow, a PhD mathematician who spends a year immersed in public policy in Washington, DC. Fellows work on the staff of a member of Congress or a congressional committee, assisting in legislative and policy areas that require scientific and technical input. The 2021-2022 AMS Congressional Fellow is AJ Stewart, who began his fellowship in September. AMS writer Scott Hershberger spoke with him in April 2021 about his journey in mathematics and his goals for his year as a Congressional staffer.

Revising bylaws related to the governance of a university may seem far removed from a mathematician's wheelhouse. But serving on Seattle University's Academic Assembly-an elected body of faculty that makes decisions on academic matters as well as issues that affect student learning-presented AJ Stewart with an unexpected opportunity to put his expertise to use.

Before Stewart, an instructor of mathematics, joined the Academic Assembly to fill in for a colleague on sabbatical, the body generally tallied votes using the Borda count. In that election method, voters rank all the candidates. But the Borda count was ill-suited to some situations faced by the Assembly, like choosing two committee members out of four candidates. Stewart proposed that the Assembly switch to a method in which voters compare two candidates at a time.

Once he explained the mathematical benefits of the pairwise system, getting buy-in from colleagues was easy. Less straightforward was the process of revising the Assembly's method of apportionment for members from different

Scott Hershberger is the communications and outreach content specialist at the AMS. His email address is s7h@ams.org.

For permission to reprint this article, please contact: reprint-permission aams.org.

DOI: https://dx.doi.org/10.1090/noti2340

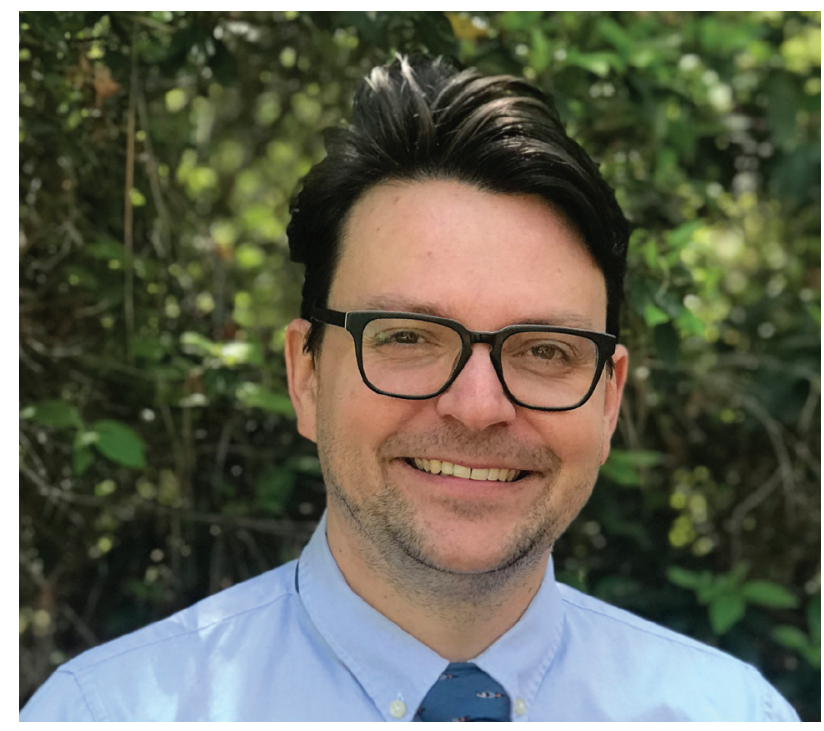

AJ Stewart, the 2021-2022 AMS Congressional Fellow.

colleges. With eight different categories of seats to apportion, "there was really a lot of going back and forth with people about how they felt about the balance of power shifting," he says.

Ultimately, the Assembly settled on a version of the Huntington-Hill method-the same technique used to 
apportion seats to states in the US House of Representatives. Now, each faculty member on the Academic Assembly represents approximately the same number of students as well as roughly the same number of faculty.

Stewart relishes policy negotiations. "I like coming to a compromise," he says. "I think it's a good feeling when people in a room [...] think that there's no way that the minds could meet, and then after a couple of weeks, people realize, 'No, there's something."

Now Stewart, who earned his PhD in mathematics in 2014 and has taught at Seattle University since then, will harness his mathematical expertise and negotiation skills to help shape national policy. In September, he moved to Washington, DC, as the 2021-2022 AMS Congressional Fellow. As a Congressional staffer, he will learn "how the sausage is made," hoping to work on issues of data privacy, tax structure, and other issues of fairness and equality.

Stewart believes that mathematicians should play an important role in creating and evaluating policies. Not only are mathematicians part of society, but they "have a specific set of skills that lend themselves to [the] policy process," he says. "There's a basis in logic, there's a basis in optimizing outcomes, there's a basis in problem-solving."

Though his desire to use mathematics for social good is clear, his path through academia to the halls of Congress was far from direct.

Stewart had a "chaotic" childhood in central Florida, moving multiple times and barely graduating high school. After a year baking bread at a steakhouse, he suddenly realized that he wanted to do something more. So he signed up for community college, where a course about proofs got him excited about mathematics. He finished his undergraduate math major at Humboldt State University and enrolled in the PhD program at the University of Oregon. Stewart seemed well on his way to a research career in pure mathematics.

But "my graduate school experience was exhausting," Stewart says. By the time he finished his dissertation on algebraic geometry, he knew that he wanted his future work to be less abstract. He took the first teaching job he could find, as an instructor at Seattle University, with the hope of encountering an area of mathematics that resonated more with him.

The turning point came at an AMS Mathematics Research Community in summer 2016. During the weeklong retreat in Snowbird, Utah, Stewart got his first taste of algebraic statistics and resolved to continue exploring the field.

"The community was really great and supportive, and it was a much better feeling than what I had had doing my pure research," he says. "From there it was like following my nose" to learn more computational tools like Julia, Python, and R.

Soon, he began teaching statistics and data science, propelled by his curiosity. For instance, when students in his consumer mathematics class expressed an interest in the
2008 financial crisis, he immersed himself in documentaries and books on the topic. That investigation led him to teach a financial mathematics course.

In the classroom, Stewart continues to connect mathematical concepts to contemporary-and local-social issues. In consumer mathematics, he asks students to investigate laws about lending licenses and calculate how much it would cost to take out a payday loan from a lender near the university. When teaching business calculus, he uses the Gini index not just as an example of integration, but also as an opportunity to discuss income inequality in the Seattle area. And in introductory statistics, he explains the Poisson distribution using data from Seattle police reports. By breaking the data down by districts, Stewart challenges students to scrutinize patterns of policing across the city and identify communities that may be subject to over-policing.

As Stewart began to incorporate more real-life examples in his teaching, his burgeoning passion for using mathematics for social good took him to Zambia on three weeklong trips in 2016 and 2017. There, he served as a project manager for Kilowatts for Humanity, a nonprofit that brings sustainable electricity to areas that lack access. On one trip, his team of mostly Seattle University students visited agricultural companies, farms, and schools to discuss a potential partnership for solar-powered irrigation. On another, his team set up a solar energy kiosk in an isolated community, working with local partners to devise a business model for the long-term upkeep of the kiosk.

"It definitely takes a different outlook. [...] It's a very difficult problem to solve," he says. But "I like difficult problems because I know there has to be a better way."

During his year as a Congressional Fellow, Stewart will face no shortage of difficult problems as a multitude of policy issues compete for priority. And as a mathematician, he wants to show policymakers the "cold, hard facts" with a compassionate approach. That empathy, he says, will be key to advancing equity throughout the policy process.

"I really would like there to be a lot more warmth and kindness across the board, but especially in mathematics," he says. "I think that we can focus on numbers, we can address harsh truths, we can be realistic-and at the same time, we can be kind."

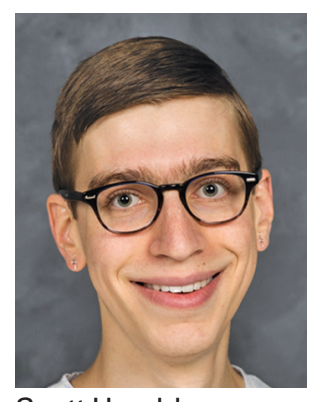

Scott Hershberger
Applications are open until February 1, 2022, for the 2022-2023 AMS Congressional Fellowship. To learn more about eligibility and how to apply, visit bit.7y/2X5Yi3D.

\section{Credits}

Photo of AJ Stewart is courtesy of Jay Shepherd.

Author photo is courtesy of Jiyoon Kang. 